\title{
Current Status of Civil-Service System in China and Its Orientation to Reform
}

\author{
Ji Pengfei \\ Department of Foundation, Northeast Petroleum University at Qinhuangdao, Qinhuangdao, China \\ Email: guicaitang@163.com
}

Received 15 February 2015; accepted 13 April 2015; published 17 April 2015

Copyright (C) 2015 by author and Scientific Research Publishing Inc. This work is licensed under the Creative Commons Attribution International License (CC BY). http://creativecommons.org/licenses/by/4.0/

c) (i) Open Access

\begin{abstract}
Service is a very important system in civil action. It runs through civil proceedings and has significant effect on the whole process of civil action. The current service of civil procedure law in China focuses on the ex officio doctrine. Its main purpose is to protect the course of litigation rather than the parties' procedural interests. In judicial practice, "difficult service" is still a problem which troubles courts at all levels. This article analyses the current status of civil-service system in China and proposes a reform-oriented service system in the country.
\end{abstract}

\section{Keywords}

Service, Service to the Parties Concerned, Status Analysis, Reform Orientation

\section{Introduction}

Service (songda 送达 in Chinese) is the behavior of the people's court to send the litigation documents and other legal documents to litigants or other participants in the proceedings in accordance with legal methods and procedures, of which “song" 送 reflects "procedural justice” while “ $d a$ " 达 covers both procedural justice and substantive justice. Because only effective service makes the proceedings move normally down to the next procedure, otherwise the defect in contact, communication and other aspects will be caused, and the proceedings will be fragmented (Qi, 2008).

Service is the informing or notification system of action at law rather than simply sending litigation documents and legal instruments. The court, through the service of notice of trial, associates the actions at law of the plaintiff, the defendant and other participants in the proceedings with the court and after a judgment of action is made for the parties in court, informs the parties concerned of the litigation outcome via service, so that the parties may enter into the next procedure. The service system organically links placing a case on file, defending, civil preservation, opening a court session, adjudicating, appellate procedure and other behaviors of all subjects 
of litigation, and shows their value in the operation of these procedures. Value of service system is mainly reflected in the following two aspects: on the one hand, standardizing the service and restricting a series of behaviors of the court; service itself shall not only comply with the statutory procedures but also meet the basic requirements of procedural safeguards. The court shall try to adopt efficient and simple ways and means of service. On the other hand, service system is the basic protection for implementation of the principle of the parties involved in litigation in civil action, since the parties involved have the right to accept the notice sent by the court, and the court is obliged to send effective notices to the parties involved on the litigation related matters, which is the basic premise for the legitimacy of civil judgment. The service pursuant to the law is the legitimacy premise for start and promoting the judicial proceedings, and interrelated aspects of legal action, having a direct impact on whether the civil proceedings can be conducted normally and timely.

\section{Status Analysis of Service in China}

Civil service system falls under the civil litigation system. Although it is an important system, it fails to attract enough attention in our country. China's current service system mainly has the following problems.

\subsection{Deficiency of Legislative Aspects}

1. Undefined Provisions on the Service Subject

The subject of civil service is not defined clearly in Chapter 7 of Civil Procedure Law. Referring to Article 83 of Opinion on the Civil Procedure Law, the court may be considered as the subject of service mandating, and the court is responsible for service in practice in general. However, as an official organ as a legal person, the specific service behavior of the court can only be completed by specific personnel. This particular staff member to be a judge, bailiff or clerk is not specified in the relevant laws, resulting in different practices of the court.

2. Undefined Provisions on Place, Time and Deadline of Service

The place of service is not expressly stipulated in Civil Procedure Law or Opinion 民事诉讼法或意见 on the Civil Procedure Law 民事诉讼法. In practice, the residence is generally taken as the place of service. In contrast to civil procedure laws in other countries, the place of service is defined clearly. In regard to the time and deadline of the service, there is neither principled provision nor specific stipulation in the section of Service. In the Civil Procedure Law, only the service deadline of copy of a bill of complaint, answer brief, notice on members of the collegiate bench and written judgment at the stage of session opening and judging is stipulated (Zong, 2007), then for the other litigation documents, what time standard will the court take to serve, how does the discretion of the judge restrict and other problems are hard to be effectively solved, unable to meet the expectability requirements on the procedures of the parties concerned.

3. Ossification and Lagging of Mode of Service

For the modes of service stipulated in the Civil Procedure Law, some are of high application conditions and some are of long term, resulting in unsuccessful service or seriously delayed service. Moreover, it can be found from the judicial practice some modes of service are convenient and safe but not stipulated in the legislation, such as agent collection, telephone, fax, electronic service, etc.

\subsection{The Problems in Judicial Practice}

The domestic mode of service is clearly stipulated in the Civil Procedure Law, including a total of six kinds: direct service, indwelling service, service by mandate, service by post, service by passing on and service by publication.

1) The problems existing in direct service

The direct service means the people's court sends specially-assigned person to hand the litigation documents or other legal documents over to the person on whom the litigation documents are to be served directly. In the juridical practice (Zhang, 2013), the persons on whom the litigation documents are to be served often go to work during working time of the court not in residence, so it is difficult to directly hand instrument over to the person on whom the litigation documents are to be served; and some the persons on whom the litigation documents are to be served have resentment against service and refuse to accept the legal documents personally, and would like to take the time to delay the proceedings and even evade their legal responsibilities.

2) The problems existing in indwelling service 
It is stipulated in Article 79 of Civil Procedure Law that if the person on whom the litigation documents are to be served or the adult family member living with him refuses to receive the documents, the person serving the documents shall ask representatives from the relevant grass-roots organization or the unit to which the person on whom the documents are to be served belongs to appear on the scene, explain the situation to them, indwelling the service. There remain a lot of problems in the practice, mainly in the difficulty in inviting the witness. Looking for the grass-roots organization or the unit itself is hard, in the second place, representatives from the relevant grass-roots organization or the unit is unwilling to witness. Because witness is not set as a statutory obligation in the law, they shall not be forced to do so. Therefore, indwelling service often can not be completed effectively (Wang, 2003).

3) The problems existing in service by mandate

It is stipulated in Article 80 of Civil Procedure Law that if direct service proves to be difficult, service of litigation documents may be entrusted to another people's court. The real intention of service by mandate is to improve service efficiency and save litigation cost. But in reality, part of the court due to partial and local interests, rarely take the initiative to cooperate with the service of litigation documents, often make an excuse for no reason; even if the entrusted courts accept the commission, in most cases, it is difficult for the entrusted courts to take out the cost from its own working time or shortage of fund to complete the entrusted matters. It can be said untimely service by mandate is one of the reasons why many cases can not be completed within the statutory trial period.

4) The problems existing in service by post

The service by post is to send the litigation documents to the person on whom the litigation documents are to be served by mail through the post office. Admittedly, service by post is a very convenient and economic mode of service. Many courts agreed with the postal sector to serve by express mail service. On the receipt of the service by post indicates the name of the documents to be served and the signature of the person on whom the litigation documents are to be served, actually reflecting "sending and accepting"; besides, service by post also relatively reduces the contrasting feeling of the person on whom the litigation documents are to be served, achieving a higher rate of successful service. Nonetheless, service by post has a significant drawback: high postage. Meanwhile, it is fixed by China's law that the subject of service can only be the people's court, and the service of litigation documents is both a right and an obligation; and the right and obligation can not be transferred to the postal department with compensation. Thus the service by post undermines the seriousness and unity of the law.

5) The problems existing in service by publication

It is stipulated in Article 84 of Civil Procedure Law that if the whereabouts of the person on whom the litigation documents are to be served is unknown, or if the documents cannot be served by the other methods specified in this Section, the documents shall be served by public announcement. A few words obviously can not regulate the complex service by publication in reality. There are multifarious modes of service by publication adopted if the whereabouts of the person on whom the litigation documents are to be served is unknown, or if the documents cannot be served directly from place to place, some courts post up on the bulletin board in the court; some post up in the residence of the person on whom the litigation documents are to be served; some make public through People's Court Daily 人民法院报. But circulation domain of People's Court Daily is narrow (Jiang and Cui, 2013), a considerable number of persons on whom the litigation documents are to be served can not see the newspaper, so the public announcement on the People's Court Daily basically can not achieve the purpose of notifying the person on whom the litigation documents are to be served. Furthermore, it is clearly defined in the law that the public announcement shall last for 60 days, so for a case, court summon and judgment shall be served by public announcement, it takes 120 days by only one service. Although the time of public announcement will not be included in the time limit, it extends the closing time and increases the litigation fatigue of the parties involved.

\section{Reform Orientation of Service System in China}

\subsection{The Modes of Service in Major Western Countries}

For the legislation on documents service in the current civil procedure laws in various countries, the principles of service running through the civil procedures fall into the following kinds:

1) The principle focusing on serving litigation documents on a party, supplemented by serving ex officio. 
Countries adopting such legislation principle are mainly common law countries. The service is initiated based on the application of a party and made by the party itself, and made by the powers and functions in individual cases. In the British Civil Procedure Law, the documents are mainly served by the party concerned in and the attorney. In the civil action in the United States, the complaints and summons are not served by the court officials but by the party concerned in, certainly by the authority in specific circumstances. In the United Kingdom, it is stipulated in the Rules of Civil Procedure that the documents issued or prepared by the court shall be served by the court unless otherwise stipulated by related rules, instructed or ordered by the court to be served by the designated by the party concerned. In the United States, writs in addition to the subpoena and summons shall be served by the US Marshal, Deputy Chief Marshal or other persons specially assigned for this purpose.

2) The principle focusing on serving ex officio, supplemented by serving litigation documents on a party. The meaning of this service is that the documents shall be served by the court ex officio unless otherwise expressly provided by the law to be served by the party concerned. Such kind of legislative principle is adopted by France, Germany, Japan and other civil law countries and Taiwan of China for civil action legislation. According to the litigation views of civil law countries, service is the act of a country to exercise the judicial power, so it shall be made by the court ex officio unless otherwise provided by law. In civil law countries, though the service is mainly made ex officio, it is also made by the party concerned. In France, the documents are served mainly by the bailiff and public prosecutor, or by the attorney. In Germany, the service from attorney to attorney is stipulated in the German Code of Civil Procedure. The method of direct service of the copy of documents by the party concerned or service by fax to the opposite party is recognized in Japan's new Code of Civil Procedure.

3) The principle of serving ex officio. The Soviet Union and China are typical countries adopting such kind of legislative principle in the Civil Procedure Law. Even if the transformation trend from ex officio doctrine to doctrine of punishment on party in China's Civil Procedure Law, the document serving by the party concerned is still prohibited in legislation (Zhao, 2008).

\subsection{Reform Orientation of Service System in China}

In the civil procedures in today's world, no matter which kind of principle of service is adopted, serving by the party concerned is absolutely prohibited, only the emphases of the serving by party concerned and serving ex officio differ. In contrast to the single practice of our country of serving by the court ex officio with absolute prohibition of serving by the party concerned, its deficiency in legislation is clear. It is necessary to gradually and moderately improve and establish the principles for civil service in China. With regard to the subject of service, consider to add the service by the party concerned except for the service by the court.

1) Subject of service

Given weakening of judge litigation system mechanism and gradual enhancement of legal concept of subject consciousness of the party concerned, the reform orientation of breaking through the court as the sole subject of service and establishing the service by the party concerned has become inevitable (Xu, 2002). According to the above discussion, the scope of subject of service in China covers the party and the attorney.

2) Object of service

It is the scope of documents to be served. To this end, regardless of civil law countries or common law countries, their basic idea is that documents issued and prepared by the court are served by the court, otherwise served by the party concerned. In consideration of the pressure of the court of hard service, it is better for us to follow the practice of civil law countries, the specified documents served by the court ex officio, but the party concerned may apply for serving by himself or his attorney, specifically including the service of 1) The exchange of legal compliant and answer brief between the parties concerned. The plaintiff sends a copy of the compliant to the defendant appellant after the court places on file and sends a copy of the appellate petition to the other party concerned after the Court of Second Instance accept and hear the case; 2) Require the opposite party concerned to make a request of confession or undertaking, for example one party requires the opposite party to reply on whether to make confession such a request may be served by the parties themselves; 3) The document showing litigation settlement or abandonment of action; 4) Papers of civil judgment except for divorce decree (Wang, 2014).

\section{Conclusion}

In summary, civil litigation system is a system which is established for the purpose of protection for the parties’ 
rights, so the service system, a part of civil litigation system, shall give priority to the protection for the parties’ rights. To be actually beneficial for the public, the existing judicial resource shall be used to protect the litigation right of good faith parties rather than being wasted on parties who attempt to evade legal responsibility, so that case can be heard fairly and efficiently. Furthermore, we shall realize that it is impossible to achieve efficient service merely depending on courts, and the service system can not be established without the involvement and support of the whole society. Only if everyone is involved in the establishment of legal system, the law can efficiently work as the guarantee of social justice.

\section{References}

Jiang Fuxiao, Cui Xingyan 姜福晓, 崔兴岩 (2013). Minshi Songda Zhidu de Xianzhuang yu Lujing Xuanze 民事送达制 度的现状与路径选择 [Current Situation and Path Selection of Civil Service System]. Shanxi Sheng Zhengfa Guanli Ganbu Xuyuan Xuebao, 26, 155-157.

Qi Shujie 齐树洁 (2008). Minshi Chengxu Fa (Di 7 ban) 民事程序法 (第七版) [The Law of Civil Procedure (Edition VII]. Xiamen: Xiamen Daxue Chubanshe.

Wang Fuhua 王福华 (2003). Minshi Songda Zhidu Zhengdanghua Yuanli 民事送达制度正当化原理 [Principles of Legalisation of Civil Service System]. Fashang Yanjiu, 47, 95-104.

Wang Wanglai 王望来 (2014). Minshi Songda Zhidu Xianzhuang ji Duice 民事送达制度现状及对策 [Current Situation and Countermeasure of Civil Service System]. Chongqing Jiaotong Daxue Xuebao, 14, 42-45.

Xu Xin 徐昕 (2002). Yingguo Minshi Susong yu Minshi Sifa Gaige 英国民事诉讼与民事司法改革 [Reform of British Civil Action and Civil Judicature]. Beijing: Zhongguo Zhegfa Daxue Chubanshe.

Zhang Yan 张燕 (2013). Minshi Songda Zhidu Ruogan Wenti Tantao 民事送达制度若干问题探讨 [Discussion on Several Issues of Civil Service System]. Henan Caijing Zhengfa Daxue Xuebao, 28, 125-134.

Zhao Zejun 赵泽君 (2008). Shilun Minshi Susong Dangshiren Songda Zhidu zhi Jiangou 试论民事诉公当事人送达制度 之建构 [Discussion on the Building of Civil Litigant Service System]. Kunming Daxue Xuebao, 8, 77-81.

Zong Ling 宗玲 (2007). Lun Woguo Minshi Songda Zhidu de Wanshan 论我国民事送达制度的完善 [Discussion on the Improvement of China's Civil Litigation System]. Faxue Zazhi, 28, 124-126. 